\title{
Research on the Teaching Reform of University Computer Basic Course Based on Internet + Background
}

\author{
Jun $\mathrm{Ma}^{1}$, LI Du ${ }^{1}$, and Qian Sun ${ }^{2}$ \\ ${ }^{1}$ Chengdu Neusoft University, Dujiangyan, Sichuan, China, 611844 \\ ${ }^{2}$ Sichuan Electric Power Design \& Consulting Co., LTD, Chengdu Sichuan, China, 610041
}

Keywords: Internet+; university computer basic course; teaching reform

\begin{abstract}
The rapid development of China's economic construction has promoted the development of information technology. The advent of the Internet+ era has increased the difficulty of university computer basic education, and it is necessary to reform and innovate the current teaching model. ${ }^{[1]}$ Based on the current development trend, the paper analyzes the current status of university computer basic course teaching and conducts a detailed study on the teaching reform of university computer basic courses in the context of Internet + .
\end{abstract}

\section{Introduction}

The university computer basic course is a very important course in the university. It belongs to the public basic course and is the ability to teach students how to use the computer correctly. The basic computer courses play a vital role in cultivating talents, improving professional skills, and job assignments. They cannot be replaced by other courses and lay a solid foundation for the study of computer courses and professional courses. Nowadays, with the continuous development and popularization of the Internet and smart phones, the difficulty of teaching the basic computer courses of universities has been increased to a great extent, and higher standards have been proposed for basic course teaching. How to integrate Internet + and curriculum to reform teaching [2] and create a new curriculum teaching model to allow students to better understand and master the computer basics course.

\section{Current Status of University Computer Basic Course Teaching}

\subsection{Lack of clear teaching goal}

The university computer basic course is a public basic course, and there are many types of professional involved, and the teaching content is extremely complicated. The unified curriculum preparation, unified syllabus and fixed teaching content of the course group are the main modes used in the current curriculum teaching. This kind of teaching model looks like a standard, but in fact the content of the curriculum is extremely poor, it is inconsistent with the professional application, there is no clear teaching goal, and there is no comprehensive consideration of differences in student majors, and the training standard for compound talents cannot be met, resulting in The student's enthusiasm for learning has declined, and ultimately he has not been able to use what he has learned. [3]

\subsection{Monotonous teaching mode}

Nowadays, the "transfer-acceptance" teaching model is widely used in university computer basic courses. In the computer room teaching, the teacher usually teaches one class of knowledge, and the rest of the time students are free to practice. In the course of explanation, the teacher usually reads the text and completes the knowledge explaining work. They can only hear the teacher's lecture on lesson, and the students just do the exercises. Throughout the teaching process, teachers are the mainstay, students are the secondary, and teachers and students lack communication and communication. Students are always in a state of passive acceptance. It is difficult to excavate the 
students' enthusiasm for learning to a certain extent, and eventually causes teachers are tired to speak, students are tired to listen.

\subsection{Relatively backward teaching content}

Computer teaching courses will change with the changes of society. New knowledge, new culture, and new technologies will be updated very quickly. However, the teaching content of university computer basic courses is relatively backward. The curriculum teaching cannot conform to the social development situation, but also low awareness, I feel that computer basic knowledge refers to computer hardware and software knowledge and basic knowledge of computer networks. The basic skill operation refers to the office operation. The computer basic course is to inform students how to use the computer and regard the computer as the main teaching task. The number of university teachers pays too much attention to the content of the textbooks, and they regard the cultivation of computer basic knowledge and basic operation skills as the focus of the classroom, which makes the teaching content relatively backward. With the continuous innovation and progress of science and technology in our country, the content of computer teaching does not meet the requirements of the development of the current computer foundation, and the understanding of computer-related knowledge is not thorough enough. With the gradual implementation of the education informatization curriculum, most primary and secondary schools have added this course. Its teaching content coincides with the teaching content of the university's computer basic courses, making students lose interest in learning and reducing teaching efficiency and teaching quality. Therefore, some related scholars have questioned the addition of basic computer courses in universities, and the contents of basic computer courses have been continuously reduced, weakened, and even some schools canceled the subject.

\section{Problems in the Process of University Computer Basic Teaching}

\subsection{Problems in learning process.}

First, because each student has a different level of education and life experience, the degree to which students accept computer knowledge is also different. For example, in the course of students' learning, due to the limitation of teaching resources, the computer knowledge they encounter is relatively small, resulting in some students' insufficient understanding of computer basic knowledge. Second, for students who have come into contact with computers, the use of methods and ways will also restrict students' computer skills to a certain extent. For example, in the process of contacting the computer, students are used for shopping, chatting, and video. Only a few students are used to review resources and browse web pages. This has no effect on the teaching reform of computer basic courses at universities.

\subsection{Problems in teaching process.}

With the rapid development of the modern economy, the dissemination of information technology has been expanded, product innovation has increased, and hardware and software have been continuously improved. However, at this stage, some schools do not pay special attention to the teaching process, which makes the computer basic teaching too old-fashioned. The backwardness of computer hardware will bring about a certain influence on students' learning ability and acceptance. The backwardness of computer software will bring about some influence on students' operational and practical forces, and there will be some differences in the teaching mode. In the current computer basic course teaching for undergraduates, the main teaching method still adopts a "learning hall", which does not reflect the main position of the students, does not fully stimulate the students' enthusiasm for learning, and is not very familiar with computer knowledge and operating procedures, does not meet the school's teaching requirements. 


\section{The Teaching Reform of University Computer Basic Courses under the Background of Internet+}

\subsection{Implement stratification teaching based on students' actual conditions.}

Some students are interested in computer classes before going to university, and they have high levels of computer skills. Some students have low levels of competence. The degree of understanding of computer knowledge during the course of lectures is very different. Prior to this teacher's explanation, an assessment should be made based on students' mastery of computer basic knowledge. Students with different basics should be divided into two groups. Different teaching plans should be developed for students in different groups so that students can keep pace with the current teaching and improve student learning efficiency. In the context of Internet + , teachers can divide the teaching content into several modules for interpretation and transfer to the Internet platform, which facilitates students' preparation and review. This will not only provide students with the convenience of learning, but also reduce the distance between students to learn, so that teaching content has become organized, stimulate students' enthusiasm for learning, and improve learning efficiency.

\subsection{The teaching content must be integrated with the profession.}

In each university, the contents of the university computer basic courses that students study are very similar. They mainly explain how to use basic office software and technical knowledge. With the advent of the Internet + era, the pace of updating information technology has been accelerated, resulting in the traditional teaching content can no longer meet the school's teaching requirements, and the teaching content is not integrated with the professional. Schools can use the Internet platform to integrate professional and computer technologies and formulate teaching programs. For example, a professional with a large amount of data analysis can teach students how to use origin lab data analysis software, so that different operating videos can be created according to different professional requirements, so that students can understand and master computer software operation knowledge.

\subsection{The teaching mode must be integrated with the Internet.}

The teaching process plays an extremely important role in the student's learning process. A good teaching model can not only improve student's learning efficiency, but also stimulate students' enthusiasm for learning and promote students' learning. In the college students' computer-based classroom under the new background, teachers should return the subject status to the students, fully demonstrate the students' own values, and stimulate the students' enthusiasm for learning. Based on the Internet + background, students can use the Internet platform to communicate with students. For example, after students have completed computer basic knowledge on the platform, they left difficult questions and asked other students and teachers to use comments to solve problems and strengthen teachers and teachers. Strengthen communication and interaction between teachers and students. In addition, students can also be tested on topics on the Internet. Students can also practice on the Internet, inspire students' enthusiasm for learning, allow students to study on their own, and consolidate computer basic knowledge frameworks. In addition, each class can also create a QQ, WeChat exchange learning group to allow students to communicate and learn, teachers can also keep abreast of the students' learning situation, develop a scientific teaching plan, adjust the teaching mode, and fundamentally improve the computer application ability of every student. [4]

\subsection{Add classroom activities.}

In the teaching of computer basic courses for undergraduates, students can also find information they need on the Internet platform, add classroom activities, enrich teaching content, expand students' horizons, and make students more knowledgeable about computers. For example, you can design interesting web pages or flash animation production activities based on a theme. This will not only stimulate students' enthusiasm for learning but will also help cultivate students' sense of 
innovation and team awareness. [5]

\section{Cultivating Computational Thinking Ability in University Computer Basic Course Teaching}

\subsection{Flip classroom teaching.}

Flipping classroom teaching refers to the teacher doing the video well in advance. The student can watch the video at home or under the classroom to learn. If student does not understand the problem, he or she can solve it in class with the teacher and the classmate. Flipping the classroom has changed the traditional teaching model and has increasingly focused on cultivating students' self-learning abilities. Students can combine previews and review with key content and can also adjust key content according to their own professional characteristics. Therefore, most scholars believe that the use of flipping classrooms in college computer basic education can improve students' learning efficiency to a certain extent. This is a bold attempt. [6] An excellent computer basic course teacher should apply the flipped classroom teaching to the course of computer introduction, such as the use of office software. Many students will simply operate the office software. Judging from the survey results of business units, the current level of computer operation of university students cannot meet the requirements of business units. [10] In this regard, it is necessary to change this phenomenon and use flipping classrooms in computer basic course teaching. In the flipping classroom, the teacher will let the students look the teaching video first to learn what they need to learn and then to explain or demonstrate it in the classroom. Because the choice is to flip classroom teaching methods, then the classroom teaching time will be more, teachers should make good use of these times, guide students to better study and experiment, and more to communicate and exchange. Before the class begins, the teacher must deal with the students' difficult problems in the learning process. The video teaching cannot replace the teacher. The teaching and guidance of the course can narrow the distance between the teacher and the students, strengthen the interaction, and improve the students' learning efficiency and teaching achievements. [7]

\subsection{Task-based teaching.}

Task organization teaching refers to the task-based teaching method. When performing tasks, the learners' cognitive abilities must be fully realized through communication, participation, interaction, and cooperation. Task-based teaching can fully mobilize the learners' own knowledge and experience, deepen the understanding and recognition of computer technology in the experiment process, and apply them in learning and learning in practice. Task-based teaching can completely mobilize the enthusiasm and initiative of students, tap students' enthusiasm for learning, and ultimately improve the results of classroom teaching. In the task-based teaching process, the responsibility of the teacher is not only to teach, but to let students master. The teacher should be responsible and take a careful look at every teaching task and reasonably formulate teaching tasks. The teacher should make clear the task of each student, replace the teaching objectives with learning tasks, strengthen the sense of responsibility of the students, and allow the students to complete their own tasks better. Learn tasks and learn with a sense of responsibility. The core of responsibility consciousness is task-driven, through the sense of responsibility to strengthen the teacher's teaching awareness; through the sense of responsibility to restrain students' learning behavior and improve learning efficiency. When studying the introduction to computational thinking, students should start with basic experiments and be proficient with the word, excel, and PPT operations. Finally, they should arrange a comprehensive task for students, such as PPT production speech, undergraduate thesis layout, and class performance ranking. [8] Some students think that the three tasks meet the actual requirements and are more suitable. Therefore, students will query the information themselves to complete the learning task. In task-based teaching, students are taught how to learn, from previous passive learning to active learning. Task-based teaching not only inspires students' enthusiasm for learning, but also improves their ability to think. 


\subsection{Guided teaching.}

Guided teaching belongs to a heuristic teaching and can be used as a teaching model of the overall guiding ideology. Its main role is to solve problems. The teacher guides students to find problems by themselves and changes the traditional knowledge explanation mode. Fully embody the main position of students in the classroom. In the activity learning process, teachers guide students to diverge their thinking and vitality, and actively participate in activities. They use practical experience, teamwork, and interactive communication to explore knowledge, train students' thinking ability, and cultivate students' observation skills and improve students' thinking ability. The role of the teacher is not to simply teach students, but to help students learn, help students solve problems, and let students have a process of self-learning, thinking and problem solving. The teacher can use how to save his name in the computer to let students deepen their knowledge of character encoding and professional knowledge. [9]

\section{Conclusion}

In summary, with the continuous innovation and progress of China's science and technology, the difficulty of university computer basic education reform has been exacerbated under the background of Internet + , so university teachers should adapt to the development of the times and integrate practical teaching and online micro-courses. Fully understand the connection between the Internet and the university computer foundation, strive to create a diversified teaching classroom, strengthen students' understanding of computer knowledge, and improve students' computer skills. This is of great help to the teaching reform of the basic computer courses in colleges and universities under the Internet + background.

\section{References}

[1] Jing Lu, Haikun Teng, Xinsheng Liu. Research on the Teaching Reform of Computer Basic Course in University under the Background of Internet $+[\mathrm{J}]$. Science and Technology Wind, 2017, (20): 36-37.

[2] Ling Wei, Danfeng Xiao. Exploration of the Teaching Mode of University Computer Basic Course under the Background of “Internet +" [J]. Guangxi Education, 2017, (47):

[3] Senyan Zhao, Tao Liu. Exploration of Cultivating Computational Thinking Ability in Basic Computer Teaching[J]. Journal of Huangshan University, 2015, (6):107-108.

[4] Minhua Liu. Exploration of Computer Basic Course Teaching Mode in Thinking University[J]. Computer Knowledge and Technology, 2016, (1):151-153.

[5] The Idea of "Internet +" Leading the Reform of University Computer Basic Courses [J]. Communications World, 2017, (3): 243-244.

[6] Lijing Liu. Research on the Teaching Reform and Practice of University Computer Basic Course under the Guidance of Ability Cultivation [J]. Computer Optical Disc Software and Applications, 2015, (3): 251-252.

[7] Yiming Chen. The Design of Flipped Classroom Teaching of University Computer Courses Under the Concept of MOOC [C]. Academic Papers, 2014.

[8] Jianhui Zhao, Xin Wang. Computer Basic Education Reform in the Process of Informatization[J]. Computer Education, 2015, (17): 76-78.

[9] Lei Wang. Research on Computer Practical Course Teaching Based on Training Skilled Talents[J]. Computer Knowledge and Technology, 2015, (11):138-139.

[10] Wancheng Niu. Investigation and Analysis on Teaching Reform of Computer Basic Courses in Colleges and Universities[J]. Science \& Technology Vision, 2013, (25):80-81. 